\title{
Parasitic infections in tambaqui from eight fish farms in Northern Brazil
}

\author{
[Infecções parasitárias em tambaqui de oito pisciculturas do Norte do Brasil] \\ M.K.R. Dias ${ }^{1}$, L.R. Neves ${ }^{2}$, R.G.B. Marinho ${ }^{1}$, M. Tavares-Dias ${ }^{1,2} *$ \\ ${ }^{1}$ Aluno de pós-graduação - Universidade Federal do Amapá -Unifap- Macapá, AP \\ ${ }^{2}$ Embrapa Amapá - Macapá, AP
}

\begin{abstract}
The aim of this study was to evaluate the parasites and parasite-host relationship in Colossoma macropomum from eight fish farms in Amapá State, Northern Brazil. A total of 12,242,559 parasites were recovered from hosts in the eight fish farms, and $87.4 \%$ of fish were infected by one or more parasite species, such as Ichthyophthirius multifiliis, Piscinoodinium pillulare, Trichodina sp. and Tetrahymena sp. (Protozoa), Anacanthorus spathulatus, Linguadactyloides brinkmanni, Mymarothecium boegeri and Notozothecium janauachensis (Monogenoidea), Procamallanus (Spirocamallanus) inopinatus (Nematoda) and Perulernaea gamitanae and Braga patagonica (Crustacea). Ichthyophthirius multifiliis presented dominance, but the greatest levels of parasitism were caused by I. multifiliis, P. pilulare, monogenoideans species and $P$. gamitanae, and all these parasites had an aggregate dispersion. The eight fish farms have differences in the parasitic infection levels, management and water quality, which are further discussed here.
\end{abstract}

Keywords: Colossoma macropomum, metazoans, parasites, protozoans, sanity

\section{RESUMO}

O presente estudo avaliou as infecções parasitárias e a relação parasito-hospedeiro em Colossoma macropomum de oito pisciculturas do estado do Amapá, norte do Brasil. Foi coletado um total de 12.242.559,0 parasitos em hospedeiros das oito pisciculturas, e 87,4\% dos peixes estavam infectados por uma ou mais espécies de parasitos, tais como Ichthyophthirius multifiliis, Piscinoodinium pillulare, Trichodina $s p$. $e$ Tetrahymena $s p$. (Protozoa), Anacanthorus spathulatus, Linguadactyloides brinkmanni, Mymarothecium boegeri $e$ Notozothecium janauachensis (Monogenoidea), Procamallanus (Spirocamallanus) inopinatus (Nematoda) e Perulernaea gamitanae $e$ Braga patagonica (Crustacea). A dominância foi de I. multifiliis, mas os maiores níveis de parasitismo foram causados por I. multifiliis, P. pilulare, espécies de monogenoideas e $\mathrm{P}$. gamitanae, e todos esses parasitos tiveram uma dispersão agregada. Nas oito pisciculturas houve diferenças quanto aos níveis de infecções parasitárias, manejo e qualidade da água, que foram aqui discutidas.

Palavras-chaves: Colossoma macropomum, metazoários, parasitos, protozoários, sanidade

\section{INTRODUCTION}

Colossoma macropomum (tambaqui) is a native Serrasalmidae of Amazon with a omnivorous natural diet (Soares et al., 2008), a characteristic that enables intensive rearing, since this species has substantial acceptance to meal (Chagas et al., 2005; Santos et al., 2013). Due to these features favoring the intensive rearing, the tambaqui is the largest native fish produced in Brazilian aquaculture, primarily in the Amazon. In 2011, the national production of tambaqui by the fishery was of 4234.9 tons while the production of aquaculture was 111, 084.1 tons (MPA, 2013). However, the perspective is of unceasing growth for the next years.

Recebido em 19 de abril de 2014

Aceito em 27 de março de 2015

*Autor para correspondência (corresponding author)

E-mail: marcos.tavares@embrapa.br 
In Amazon, the tambaqui has been reared in ponds (Tavares-Dias et al., 2006; Delgado et al., 2011; Godoi et al., 2012) and net-cage (Morais et al., 2009; Santos et al.; 2013). Due to the increasing intensive culture difficulties associated with infections by ectoparasites have been intensified (Tavares-Dias et al., 2006; Morais et al., 2009; Delgado et al., 2011, Godoi et al., 2012; Santos et al., 2013). The situation is even more problematic when management is deficient and the low levels of dissolved oxygen in the water are inappropriate for the cultivation of the species (Morais et al., 2009; Santos et al., 2013). Parasites may inversely influence the diet and development of the cultivated hosts, reduce body conditions and fish quality, affecting the productivity and commerce. Therefore, it is crucial to identify the agents responsible for parasite infections in farmed fish and evaluate sanitary conditions to implement and/or improve prophylactic management used in fish farms (Tavares-Dias et al., 2006; Delgado et al., 2011) to efficiently interfere in the process.

The aim of this study was to identify tambaqui parasites in eight fish farms in the municipality of Macapá, Amapá State. Furthermore, we evaluate host-parasites relationship and sanitary conditions of the fish farms investigated.

\section{MATERIAL AND METHODS}

Ten specimens of Colossoma macropomum were collected in each of the eight fish farm investigated in the municipality of Macapá, Amapá State. Sampling took place every three months, from September 2009 to April 2011 when we examined every collected fish and performed parasitological analysis in every farm in with differential management characteristics (Table 1).

The mouth, opercula, gills and gastrointestinal tract of each necropsied fish was examined. The gills removed were fixed in formalin $5 \%$ and used to collect ectoparasites. The gastrointestinal tract was removed in order to detect endoparasites. Methods of sampling, fixing, preparation of parasites for identification and counting followed previous recommendations (Eiras et al., 2006).

The ecological terms adopted were those recommended by Rohde et al. (1995) and Bush et al. (1997). The variance-mean ratio of parasite abundance (index of dispersion) and Poulin discrepancy index (D) were computed using the software Quantitative Parasitology 3.0 and were employed to detect distribution patterns of the parasite infracommunity (Rózsa et al., 2000) in species with prevalence $\geq 10 \%$. Index of dispersion (ID) significance was tested using the statistic $d$ according to Ludwig and Reynolds (1988) for each infracommunity.

Throughout fish sampling and in each fish farm we determined $\mathrm{pH}$ with a digital $\mathrm{pH}$ meter $(\mathrm{pH}-$ 100, YSI), temperature and dissolved oxygen levels with a digital oximeter (DO-200, YSI). The mean water temperature of $C$. macropomum ponds in eight fish farms was similar, while the $\mathrm{pH}$ was lower only in one of the fish farms. Low oxygen levels were similar in all fish farms, and remained under $3 \quad \mathrm{mg} / \mathrm{L}$.

Table 1. Mean values \pm standard deviation of weight and length, geographic localization, stocking density and total parasite prevalence (P) in Colosssoma macropomum from eight fish farms in the State of Amapá (Brazil). EF: Examined fish; PF: parasitized fish; P: Prevalence

\begin{tabular}{|c|c|c|c|c|c|c|}
\hline Fish farms & Geographic coordinates & Weight (g) & $\begin{array}{l}\text { Length } \\
(\mathrm{cm})\end{array}$ & $\begin{array}{l}\text { Density } \\
\left(\text { fish } / \mathrm{m}^{2}\right)\end{array}$ & $\mathrm{EF} / \mathrm{PF}$ & $\begin{array}{c}\mathrm{P} \\
(\%)\end{array}$ \\
\hline $\mathrm{P} 1$ & $00^{\circ} 08^{\prime} 42.3^{\prime \prime} \mathrm{N}-051^{\circ} 06^{\prime} 04.2^{\prime \prime} \mathrm{W}$ & $527.3 \pm 279.42$ & $29.7 \pm 6.29$ & 2.5 & $54 / 54$ & 100 \\
\hline $\mathrm{P} 2$ & $0^{\circ} 0$ '21.7"S-05107'23.1"W & $514.1 \pm 385.1$ & $26.6 \pm 9.52$ & 2.0 & $59 / 58$ & 98.3 \\
\hline P3 & $0^{\circ} 00^{\prime} 13.5^{\prime \prime} \mathrm{S}-051^{\circ} 06^{\prime} 12.8^{\prime \prime} \mathrm{W}$ & $884.7 \pm 676.73$ & $33.1 \pm 13.78$ & 2.8 & $68 / 56$ & 82.8 \\
\hline $\mathrm{P} 4$ & $00^{\circ} 01^{\prime} 48.3^{\prime \prime S}-051^{\circ} 07^{\prime} 52.9^{\prime \prime} \mathrm{W}$ & $332.9 \pm 265.98$ & $22.6 \pm 9.73$ & 2.0 & $68 / 61$ & 89.7 \\
\hline P5 & $0^{\circ} 04^{\prime} 15.4^{\prime \prime} \mathrm{N}-051^{\circ} 02^{\prime} 16.9^{\prime \prime} \mathrm{W}$ & $303.8 \pm 145.53$ & $26.4 \pm 4.5$ & 2.8 & $70 / 65$ & 92.9 \\
\hline P6 & $0^{\circ} 02^{\prime} 31.4^{\prime \prime} \mathrm{S}-051^{\circ} 07^{\prime} 34.4^{\prime \prime} \mathrm{W}$ & $747.4 \pm 485.09$ & $32.8 \pm 8.48$ & 2.3 & $71 / 70$ & 98.6 \\
\hline P7 & $00^{\circ} 00^{\prime} 13.2^{\prime \prime S}-051^{\circ} 06^{\prime} 10.9^{\prime \prime} \mathrm{W}$ & $397.3 \pm 168.92$ & $27.9 \pm 4.8$ & 0.8 & $52 / 51$ & 98.1 \\
\hline P8 & $0^{\circ} 00^{\prime} 04.5^{\prime \prime} \mathrm{N}-051^{\circ} 05^{\prime} 52.1^{\prime \prime} \mathrm{W}$ & $384.3 \pm 219.35$ & $37.2 \pm 43.9$ & 1.5 & $31 / 23$ & 74.2 \\
\hline
\end{tabular}


Colossoma macropomum of the fish farms were parasitized by Ichthyophthirius multifiliis, Piscinoodinium pillulare, Trichodina sp., Tetrahymena sp. (Ciliophora), Anacanthorus spathulatus, Linguadactyloides brinkmanni, Mymarothecium boegeri, Notozothecium janauachensis (Dactylogyridae), Procamallanus (Spirocamallanus) inopinatus (Camallanidae), Perulernaea gamitanae (Lerneidae) and Braga patagonica (Cymothoidae). High levels of infection by I. multifiliis were similar in the eight fish farms. However, infection levels by $P$. pillulare were greater only in $25 \%$ of the fish farms (Table 2-3). Only A. Spathulatus was collected from this fish in all of the eight fish farms. Mymarothecium boegeri did not occur solely in two fish farms (P2 and P8), Linguadactyloides brinkmanni was collected in fish from four fish farms (P1, P3, P4 and P6) and $N$. janauachensis in fish from three fish farms (P1, P3 and P6). However, the prevalence of monogenoidean species was similar among fish farms from the State of Amapá, while the intensity of these parasites was greater in three establishments (Table 3).

Table 2. Protozoans of Colosssoma macropomum gills in eight fish farms in the State of Amapá (Brazil). EF: Examined fish, PF: Parasitized fish, P: Prevalence, MI: Mean intensity, MA: Mean abundance, TNP: Total number of parasites

\begin{tabular}{ccccccccccc}
\hline & \multicolumn{4}{c}{ Ichthyophthirius multifiliis } & \multicolumn{4}{c}{ Piscinoodinium pillulare } \\
\hline $\begin{array}{c}\text { Fish } \\
\text { farms }\end{array}$ & EF/PF & $\begin{array}{c}\text { P } \\
(\%)\end{array}$ & MI & MA & TNP & EF/PF & P & MI & MA & TNP \\
\hline P1 & $54 / 53$ & 98.1 & 174,955 & 171,715 & $9,272,628.0$ & $54 / 21$ & 38.9 & 73,203 & 28,468 & $1,537,255.0$ \\
P2 & $58 / 48$ & 82.8 & 272,541 & 225,551 & $13,081,986.0$ & $58 / 41$ & 70.7 & 86,533 & 61,170 & $3,547,866.0$ \\
P3 & $68 / 56$ & 82.4 & 357,589 & 294,485 & $20,025,001.0$ & $68 / 34$ & 50.0 & 75,458 & 37,729 & $2,565,573.0$ \\
P4 & $68 / 61$ & 89.7 & 236,790 & 212,414 & $14,444,183.0$ & $68 / 37$ & 54.4 & 62,116 & 33,798 & $2,298,295.0$ \\
P5 & $70 / 63$ & 90.0 & 194,314 & 174,881 & $12,241,708.0$ & $70 / 21$ & 30.0 & 17,909 & 5,373 & $376,090.0$ \\
P6 & $71 / 67$ & 94.4 & 373,837 & 352,775 & $25,047,053.0$ & $71 / 37$ & 52.1 & 54,725 & 28,518 & $2,024,816.0$ \\
P7 & $52 / 51$ & 98.1 & 136,917 & 134,283 & $6,982,743.0$ & $52 / 38$ & 73.1 & 25,265 & 18,463 & $960,077.0$ \\
P8 & $31 / 22$ & 71.0 & 323,778 & 229,778 & $7,123,124.0$ & $31 / 13$ & 41.9 & 35,132 & 14,733 & $456,722.0$ \\
\hline
\end{tabular}

Table 3. Helminth of Colosssoma macropomum in eight fish farms in the State of Amapá (Brazil). EF: Examined fish, PF: Parasitized fish, P: Prevalence, MI: Mean intensity, MA: Mean abundance, TNP: Total number of parasites

\begin{tabular}{ccccccccccc}
\multicolumn{9}{c}{ Monogenoidea } \\
$\begin{array}{c}\text { Fish } \\
\text { farms }\end{array}$ & EF/PF & P & MI & MA & TNP & EF/PF & $\begin{array}{c}\text { P } \\
(\%)\end{array}$ & MI & MA & TNP \\
\hline P1 & $54 / 54$ & 100 & 570.5 & 570.5 & 30,805 & $54 / 0$ & 0 & 0 & 0 & 0 \\
P2 & $58 / 57$ & 98.3 & 108.6 & 106.7 & 6190 & $58 / 1$ & 1.7 & 1.0 & 0.02 & 1 \\
P3 & $68 / 56$ & 82.4 & 492.5 & 405.6 & 27,579 & $68 / 0$ & 0 & 0 & 0 & 0 \\
P4 & $68 / 61$ & 89.7 & 372.1 & 333.8 & 22,698 & $68 / 3$ & 4.4 & 2.0 & 0.09 & 6 \\
P5 & $70 / 65$ & 92.9 & 164.1 & 152.4 & 10,667 & $70 / 18$ & 25.7 & 1.0 & 0.2 & 18 \\
P6 & $71 / 70$ & 98.6 & 804.3 & 793.0 & 56,303 & $71 / 3$ & 4.2 & 2.7 & 0.1 & 8 \\
P7 & $52 / 51$ & 98.1 & 168.1 & 164.9 & 8575 & $52 / 3$ & 5.8 & 2.7 & 0.1 & 8 \\
P8 & $31 / 23$ & 74.2 & 166.2 & 123.3 & 3822 & $31 / 1$ & 3.2 & 1.0 & 0.03 & 1 \\
\hline
\end{tabular}

Procamallanus (S.) inopinatus was collected in the intestine of $C$. macropomum in some fish farms, but the highest prevalence occurred in one of the fish farms (Table 3). Trichodina sp. (13.2\% of prevalence and mean intensity of $1.023 \pm 823)$ and Tetrahymena sp. $(19.1 \%$ of prevalence and mean intensity of $6.249 \pm 6.513)$ occurred only in one of the fish farms (P4).
Lerneids $P$. gamitanae were found parasitizing C. macropomum from only two fish farms ( $\mathrm{P} 4$ and P6). In the P4 fish farm, only the mouth of fish with low levels of infection was parasitized (prevalence $=10.3 \%$ and mean intensity $=$ $1.8 \pm 1.07)$. In the other fish farm (P6), mouth (prevalence $=64.3 \%$ and mean intensity $=$ $4.9 \pm 3.2$ ) and gills (prevalence $=47.1 \%$ and mean intensity $=2.2 \pm 1.4$ ) were parasitized. Tambaqui 
from one fish farm (P6) of Amapá State was parasitized by isopod $B$. patagonica, but with low prevalence $(16.0 \%)$ and a 2.0 parasite/host intensity. Braga patagonica was found in the dorsal region of hosts, close to the dorsal fin, causing the loss of scales and skin, triggering a critical inflammatory process in the region.

There was a dominance of infection by $I$. multifiliis followed by $P$. pillulare in $C$. macropomum from eight fish farms. Camalanids $P$. (S.) inopinatus were the only endoparasites collected of $C$. macropomum and they presented low levels of parasitic infection. Overall, parasitism caused by $P$. gamitanae and $B$. patagonica in $C$. macropomum was low (Table 4). The infracommunities of I. multifiliis, $P$. pillulare, monogenoideans species and $P$. gamitanae had an aggregate dispersion pattern (Table 5).

Table 4. Colosssoma macropomum parasites in fish farms in the State of Amapá (Brazil). EF: Examined fish, PF: Parasitized fish, MI: Mean Intensity, SD: Standard deviation, MA: Mean abundance TNP: Total Number of Parasites, RD: Relative dominance, SI: Site of infection

\begin{tabular}{|c|c|c|c|c|c|c|c|}
\hline Parasites & SI & $\mathrm{EF} / \mathrm{PF}$ & $\mathrm{P}(\%)$ & $\mathrm{MI} \pm \mathrm{SD}$ & MA & TNP & $\mathrm{RD}$ \\
\hline $\begin{array}{l}\text { Ichthyophthirius } \\
\text { multifiliis }\end{array}$ & Gills & $473 / 424$ & 89.6 & $255,232.1 \pm 246,808.4$ & $228,792.0$ & $108,218,426$ & 0.88528 \\
\hline $\begin{array}{l}\text { Piscinoodinium } \\
\text { pillulare }\end{array}$ & Gills & $473 / 245$ & 51.8 & $56,191.0 \pm 62,266.7$ & $29,105.0$ & $13,766,694$ & 0.11262 \\
\hline Tetrahymena sp. & Gills & $473 / 13$ & 2.7 & $6,249.0 \pm 1,457.6$ & 172.0 & 81,233 & 0.00066 \\
\hline Trichodina sp. & Gills & $473 / 147$ & 1.9 & $1,023.0 \pm 176.2$ & 19.5 & 9,203 & 0.00007 \\
\hline $\begin{array}{l}\text { Monogenoidea } \\
\text { species }\end{array}$ & Gills & $473 / 424$ & 89.6 & $393.0 \pm 652.1$ & 352.3 & 166,639 & 0.00136 \\
\hline $\begin{array}{l}\text { Procamallanus }(S .) \\
\text { inopinatus }\end{array}$ & Intestine & $473 / 19$ & 4.0 & $2.2 \pm 0.7$ & 0.09 & 42 & - \\
\hline $\begin{array}{l}\text { Perulernaea } \\
\text { gamitanae }\end{array}$ & Gills & $473 / 33$ & 6.9 & $2.2 \pm 0.7$ & 0.2 & 73 & - \\
\hline $\begin{array}{l}\text { Perulernaea } \\
\text { gamitanae }\end{array}$ & Mouth & $473 / 53$ & 11.2 & $4.5 \pm 1.7$ & 0.5 & 237 & - \\
\hline Braga patagonica & Body & $473 / 12$ & 2.5 & $1.0 \pm 0.2$ & 0.03 & 12 & - \\
\hline
\end{tabular}

Table 5. Dispersion Index (ID), discrepancy index (D) and statistic $d$ for the parasitic infracommunities in Colossoma macropomum from fish farms in the State of Amapá (Brazil)

\begin{tabular}{lccc}
\hline Parasites & ID & $d$ & D \\
\hline Ichthyophthirius multifiliis & 16.125 & 92.67 & 0.400 \\
Piscinoodinium pillulare & 22.114 & 113.93 & 0.665 \\
Monogenoidea species & 13.323 & 81.45 & 0.446 \\
Perulernaea gamitanae & 5.717 & 42.755 & 0.924 \\
\hline
\end{tabular}

\section{DISCUSSION}

In the eight fish farms in this study, the fish collected presented different weight and length, because they were examined in two rearing stages - fingerling and fattening. In these fish farms the stocking densities and management also varied, but the high parasitic prevalence was similar, due to similar management used and the reduced expertise in the activity demonstrated by fish farmers. However, the high parasitic prevalence $(100 \%)$ in C. macropomum in this study was similar to prevalence $(96.5 \%)$ reported by Godoi et al. (2012) for this same fish when farmed in Rondônia State.
Four species of Protozoa, four species of Monogenoidea, one Nematoda and two species of Crustacea were found in C. macropomum in fish farms from Amapá State. Santos et al. (2013) described only two species of Protozoa, two species of Monogenoidea and one species of Hirudinea in tambaqui rearing in net-cage in the State of Amapá. For the same host of ponds in the State of Amazonas, Tavares-Dias et al. (2006) reported only one protozoan species, one monogenoidea and one myxosporean. Godoi et al. (2012) identified six species of Monogenoidea and one species of Crustacea in tambaqui reared in the State of Rondônia. Therefore, farmed tambaqui present high ectoparasites diversity, which have a direct life 
cycle. In fish farms the presence of endoparasites may be occasionally due to the absence or low occurrence of the infecting stages in intermediate hosts of endohelminths - parasites with a heteroxenic life cycle.

Colossoma macropomum in this study had high levels of infection by I. multifiliis in the eight fish farms investigated. Trichodina sp. occurred only in fish from one of the fish farms. However, infection levels by $P$. pillulare were greater in only $25 \%$ of the fish farms due to poor environmental quality, which benefits the proliferation of both protozoans that are transmitted directly from fish to fish (Colorni, 2008; Santos et al., 2013). It occurs primarily in reared fish in high stocking densities and poor management conditions (Banu and Khan 2004), as occurred with the fish in the present study.

In C. macropomum gills only A. Spathulatus was collected from the host in the eight fish farms, while $M$. boegeri, L. brinkmanni and $N$. janauachensis were found in fish in a few fish farms. Even though it was not possible to determine the prevalence for each monogenoideans species, L. brinkmanni and $N$. janauachensis were the least prevalent species in samples. Morais et al. (2009) also reported such differences in the prevalence of these monogenoidean species in farmed $C$. macropomum in net-cage in the State of Amazonas. However, the prevalence of monogenoideans was similar among the fish farms investigated here, while the intensity of these parasites was greater only in three fish farms, due to differential management.

Nematode $P$. (S.) inopinatus occurred in $C$. macropomum in $75 \%$ of the fish farms investigated, but in low prevalence. However, only fish from one fish farm had higher prevalence, probably because of the presence of this nematode's infecting stages in ponds. In this farm, the ponds are supplied with water from a river and the floodplain, where it is possible to find arthropod species. Chironomids are intermediary hosts of $P$. (S.) inopinatus (Moreira et al., 2009), a nematode with low parasitic specificity, which requires fish as paratenic or definite hosts (Silva et al., 2011). Still, Camallanidae species may be damaging to reared fish, because when it is in the presence of a great quantity of intermediary hosts with infecting stages in this artificial environment, it may lead to high levels of parasitism.

Perulernaea gamitanae infested the mouth and gills of $C$. macropomum in fish farms investigated. However, fish from one fish farm were the source for the introduction of this ectoparasite in the other fish farm, when it acquired tambaqui for fattening. Such results highlight the importance of the quarantine period in order to avoid the transference of parasites among fish farms. In general, this procedure has not been used by most of the fish farms, including those in Amapá State, resulting in the use of chemotherapeutic treatments. To eliminate and control $P$. gamitanae in these fish, $100 \mathrm{~g}$ of Diflubenzuron $/ 1000 \mathrm{~m}^{3}$ of pond may be used (Tavares-Dias et al., 2011), since copepodits are capable of surviving for seven days without the host.

The isopod $B$. patagonica occurred in low prevalence and intensity in $C$. macropomum in only one fish farm, and was found parasitizing the dorsal region of hosts, close to the dorsal fin. Wild fish (Hoplias malabaricus, Curimatidae species and Ancestrorhynchus spp.) were the source of the parasites for $C$. macropomum in this study, because the gills of these wild fish from the river that supplies the fish farm were also found with gills infection by $B$. patagonica. Isopod species are parasites that can also cause loss of blood, reduction of gill filaments and respiratory deficiencies, in addition to reducing the development of fish (Carvalho et al., 2004), which are undesirable consequences in fish farms.

In this study there was a dominance of $I$. multifiliis followed by $P$. pillulare. High prevalence of both protozoans was similar to previous descriptions for the same host reared in net-cage (Santos et al., 2013), while mean intensity and abundance were superior. We attribute this result to the low environmental quality in ponds in fish farms. Levels of infection by Tetrahymena sp. in the gills of $C$. macropomum were similar to the ones described for Carnegiella strigata, while parasitism by Trichodina sp. were similar to the levels of infection in Carnegiella martae (Tavares-Dias et al., 2010), both hosts collected in the Negro River. However, Tetrahymena $\mathrm{sp}$. is a ciliate with rare occurrence in Brazilian fish, 
contrasting with Trichodina sp., a species which parasites wild and farmed fish populations.

High levels of infection by monogenoideans were observed in the gills of $C$. macropomum, and the prevalence was similar to the one described for this host in net-cage from the Paru Lake-AM (Morais et al., 2009) and Matapi River-AP (Santos et al., 2013) and in fish farmed from the State of Rondônia (Godoi et al., 2012). Despite that, mean intensity and mean abundance were higher than the ones found in those studies, due to the peculiar condition of the environment from each fish farm. Parasitism caused by monogenoideans species was due to low $\mathrm{pH}$ and oxygen levels in the rearing pond (Banu and Khan, 2004; Modu et al., 2012), and also by high temperatures in the region.

Overall, parasitism caused by $P$. gamitanae and $B$. patagonica in $C$. macropomum farmed in the State of Amapá was low. The levels of infection by $P$. gamitanae were similar to the ones described for this same host farmed in the State of Rondônia (Godoi et al., 2012). However, those levels were greater if compared to the corresponding host reared in the State of Amazonas (Morais et al., 2011). High levels of infection by $P$. gamitanae in fingerlings of tambaqui farmed in the Peruvian Amazon resulted in $100 \%$ of mortality of the fish (Delgado et al., 2011). This lerneid seem have parasitic specificity since it infected only $C$. macropomum and hybrids of C. macropomum $\mathrm{x}$ Piaractus mesopotamicus and C. macropomum $\mathrm{x}$ Piaractus brachypomum (Tavares-Dias et al., 2011). In addition, $P$. gamitanae may cause inflammatory process, hyperplasia and gills anemia, which leads to the death of farmed fish, (Delgado et al., 2011; Morais et al., 2011; Tavares-Dias et al., 2011), mainly of fingerlings with high parasitic infection levels.

In C. macropomum, infracommunities of $I$. multifiliis, $P$. pillulare, Monogenoidea and $P$. gamitanae had an aggregate dispersion, indicating stability in the dynamics of the hostparasite association. This pattern of aggregate dispersion is highly influenced by genetic, environmental and immunological factors of hosts (Moller, 2006). However, in the fish farm, the environment and the fish aggregation are the factors that primarily affect the pattern of dispersion of ectoparasites.
Finally, a great parasitic diversity occurred in $C$. macropomum, composed mainly by ectoparasites with a high level of infection. Qualitative and quantitative differences in ectoparasites of tambaqui were caused mainly by the management adopted (i.e, food quality and quantity, and sanitary quality of fish farms), as well as by low levels of dissolved oxygen and differences regarding the source of water used to supply the ponds. The results demonstrate the need for adopting adequate prophylactic actions in these fish farms in order to avoid economic loss by epizooties. This is the first report of Tetrahymena and $P$. (S.) inopinatus for farmed C. macropomum in Brazil, and extends the geographic distribution of this ciliate to eastern Amazon.

\section{ACKNOWLEDGEMENTS}

This research followed the principles adopted by the Colégio Brasileiro de Experimentação Animal (COBEA). The authors are indebted to $\mathrm{CNPq}$ for the financial support (Proc. 578159/2008-2) and for the PQ scholarship awarded to Tavares-Dias, $\mathrm{M}$.

\section{REFERENCES}

BANU, A.N.H.; KHAN, M.H. Water quality, stocking and parasites of freshwater fish in four selected areas of Bangladesh. Pakistan J. Biol. Sci., v.7, p.436-440, 2004.

BUSH, A.O.; LAFFERTY, K.D.; LOTZ, J.M. et al. Parasitology meets ecology on its own terms: Margolis et al. revisited. J. Parasitol, v. 83, p.575-583, 1997.

CARVALHO, L.N.; ARRUDA, R.; DEL-CLARO, K. Host-parasite interactions between the piranha Pygocentrus nattereri (Characiformes: Characidae) and isopods and branchiurans (Crustacea) in the Rio Araguaia basin, Brazil. Neotrop. Ichthyol., v.2, p.9398, 2004.

CHAGAS, E.C.; GOMES, L.C.; MARTINS JUNIOR, H. et al. Desempenho de tambaqui cultivado em tanques-rede, em lago de várzea, sob diferentes taxas de alimentação. Pesqui. Agropecu. Bras., v.8, p.833835,2005

COLORNI, A. Diseases caused by Ciliophora. In: EIRAS, J.C.; SEGNER, H.; WAHLI, T.; KAPOOR, B.G. (Eds.). Fish diseases. Enfield: Ed. Science Publishers., 2008. p.570-602. 
DELGADO, P.M.; DELGADO, J.P.M.; ROSA, J.V.A. et al. Infestación massiva por Perulernaea gamitanae (Crustacea: Cyclopoida: Lernaeidae) en juveniles de gamitana, cultivados en la Amazônia peruana. Vet. Méx. v.42, p.59-64, 2011.

EIRAS, J.C.; TAKEMOTO, R.M.; PAVANELLI, G.C. Métodos de estudo e técnicas laboratoriais em parasitologia de peixes. 2.ed. Maringá: Eduem, 2006. 199p.

GODOI, M.M.I.M.; ENGRACIA, V.; LIZAMA, M.L.A.P. et al. Parasite-host relationship between the tambaqui (Colossoma macropomum Cuvier 1818) and ectoparasites, collected from fish farms in the city of Rolim de Moura, State of Rondônia, western Amazon, Brazil. Acta Amaz., v.42, p.515-524, 2012.

LUDWIG, J.A.; REYNOLDS, J.F. Statistical ecology: $a$ primer on methods and computing. New York: Wiley-Interscience, 1988. 337p.

MODU, B.M.; SIFUL, M.; KASIN, M.K. et al. Effects of water quality and monogenean parasite in gills of freshwater cat fish, Hemibagrus nemurus Valenciennes 1840. Cur. Res. J. Biol. Sci. v. 4, p. 242246, 2012.

MOLLER, A.P. Parasitm and the regulation oh host populations. In: THOMAS, F.; RENAUD, F.; GUÉGAN, J.F. Parasitism and ecosystems. New York: Oxford University Press, 2006. p.43-53.

MORAIS, A.M.; VARELLA, A.M.B.; MALTA, J.C.O. Perulernaea gamitanae (Crustacea: Lernaeidae) parasitizing Colossoma macropomum (Osteichthyes: Serrasalminae) raised in captivity in the Brazilian Amazon. Biol. Geral Exper., v.11, p.23-28, 2011.

MORAIS, A.M.; VARELLA, A.M.B.; VILLACORTA-CORREA, M.A.; MALTA, J.C.O. A fauna de parasitos em juvenis de tambaqui Colossoma macropomum (Cuvier, 1818) (Characidae: Serrasalminae) criados em tanques-rede em lago de várzea da Amazônia central. Bio. Geral Exper., v.9, p.14-23, 2009

MOREIRA, L.H.A.; TAKEMOTO, R.M.; YAMADA F.H. et al. Ecological aspects of metazoan endoparasites of Metynnis lippincottianus (Cope, 1870) (Characidae) from upper Paraná River floodplain, Brazil. Helminthologia, v.46, p.214-219, 2009.
PRODUÇÃO pesqueira e aquícola 2011. Brasília, DF: Ministério da Pesca e Aquicultura, 2013. 60p.

ROHDE, K.; HAYWARD, C.; HEAP, M. Aspects of the ecology of metazoan ectoparasites of marine fishes. J. Parasitol., v.25, p.945-970, 1995.

RÓZSA, L.; REICZIGEL, J.; MAJOROS, G. Quantifying parasites in samples of hosts. $J$. Parasitol., v.86, p.228-232, 2000.

SANTOS, E.F.; TAVARES-DIAS, M.; PINHEIRO, D.A. et al. Fauna parasitária de tambaqui Colossoma macropomum (Characidae) cultivado em tanque-rede no estado do Amapá, Amazônia oriental. Acta Amaz., v.43, p.107-114, 2013.

SILVA, A.M.O.; TAVARES-DIAS, M.; FERNANDES, J.S. Helminthes parasitizing Semaprochilodus insignis Jardine, 1841 (Osteichthyes: Prochilodontidae) from the central Amazonia (Brazil), and their relationship with the host. Neotrop. Helminthol., v.5, p.225-233, 2011.

SOARES, M.G.M.; COSTA, E.L.; SIQUEIRASOUZA, F.K. et al. Peixes de lagos do médio Rio Solimões. 2.ed. Manaus: Instituto Piatam, 2008. 160p.

TAVARES-DIAS, M.; LEMOS, J.R.G.; ANDRADE, S.M.S. et al. Ocorrência de ectoparasitos em Colossoma macropomum Cuvier, 1818 (Characidae) cultivados em estação de pisciculturas na Amazônia Central. In: CONGRESO IBEROAMERICANO VIRTUAL DE ACUICULTURA, 4., 2006. Anais..., 2006. p.726-731 Disponível em: <http://www.revistaaquatic.com/civa2006/coms/compl eto.asp?cod $=150>$.

TAVARES-DIAS, M.; LEMOS, J.R.G; MARTINS, M.L. Parasitic fauna of eight species of ornamental freshwater fish species from the middle Negro River in the Brazilian Amazon region. Rev. Bras. Parasitol. Vet., v.19, p.103-107, 2010.

TAVARES-DIAS, M.; NEVES, L.R.; SANTOS, E.F. et al. A Perulernaea gamitanae (Copepoda: Lernaeidae) parasitizing tambaqui (Colossoma macropomum) (Characidae) and the hybrids tambacu and tambatinga, cultured in Northern Brazil. Arq. Bras Med. Vet. Zoot., v.63, p.988-995, 2011.

ZAR, J.H. Biostatistical analysis. 5. ed. New Jersey: Prentice Hall, 2010. 944 p. 